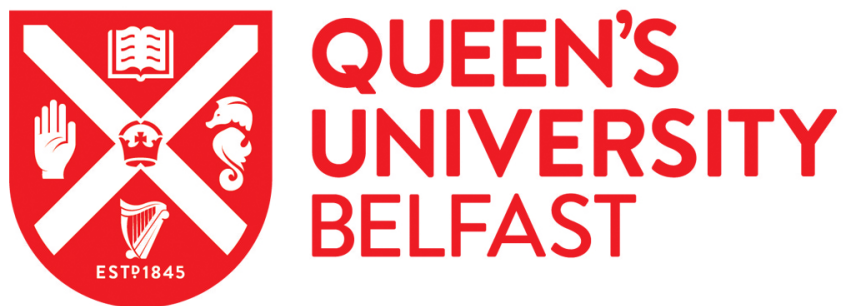

\section{Interlocking directorates and conflicts of interest: The Rotterdamsche Bankvereeniging, Müller \& Co. and the Dutch financial crisis of the} \section{0s}

Colvin, C. L. (2014). Interlocking directorates and conflicts of interest: The Rotterdamsche Bankvereeniging, Müller \& Co. and the Dutch financial crisis of the 1920s. Business History, 56(2), 314-334.

https://doi.org/10.1080/00076791.2013.771342

Published in:

Business History

Document Version:

Peer reviewed version

Queen's University Belfast - Research Portal:

Link to publication record in Queen's University Belfast Research Portal

\section{Publisher rights}

Copyright 2013 Taylor \& Francis

This manuscript is distributed under a Creative Commons Attribution-NonCommercial-NoDerivs License

(https://creativecommons.org/licenses/by-nc-nd/4.0/), which permits distribution and reproduction for non-commercial purposes, provided the author and source are cited.

\section{General rights}

Copyright for the publications made accessible via the Queen's University Belfast Research Portal is retained by the author(s) and / or other copyright owners and it is a condition of accessing these publications that users recognise and abide by the legal requirements associated with these rights.

Take down policy

The Research Portal is Queen's institutional repository that provides access to Queen's research output. Every effort has been made to ensure that content in the Research Portal does not infringe any person's rights, or applicable UK laws. If you discover content in the

Research Portal that you believe breaches copyright or violates any law, please contact openaccess@qub.ac.uk. 
Interlocking directorates and conflicts of interest: The Rotterdamsche Bankvereeniging, Müller \& Co. and the Dutch financial crisis of the 1920s

\author{
Christopher L. Colvin
}

Queen's University Management School, Queen's University Belfast, Belfast, UK

Email: chris.colvin@qub.ac.uk

The author thanks Gerben Bakker, Ariëtte Dekker, Philip Fliers, Abe de Jong, Joost Jonker, Tim Leunig and two anonymous referees for commenting on earlier versions of this paper, and Dick Wijmer for help with archival sources.

Christopher L. Colvin is a Lecturer in Business Economics at Queen's University Belfast and a Research Associate at Queen's University Centre for Economic History. Before that he was a Max Weber Postdoctoral Fellow at the European University Institute, Florence. He was awarded the biannual European Business History Association Dissertation Prize in 2012 for a PhD completed at the London School of Economics in 2011. 


\section{Interlocking directorates and conflicts of interest: The Rotterdamsche Bankvereeniging, Müller \& Co. and the Dutch financial crisis of the 1920s}

How can interlocking directorates cause financial instability for universal banks? A detailed history of the Rotterdamsche Bankvereeninging in the 1920s answers this question in a case study. This large commercial bank adopted a new Germanstyle universal banking business model from the early 1910s, sharing directors with the firms it financed as a means of controlling its interests. Then, in 1924, it required assistance from the Dutch state in order to survive a bank run brought on by public concerns over its close ties with Müller \& Co., a trading conglomerate that suffered badly in the economic downturn of the early 1920s. Using a new narrative history combined with an interpretive model, this article shows how the interlocking directorates between the bank and this major client, and in particular the direction of influence of these interlocks, resulted in a conflict of interest that could not be easily overcome.

Keywords: interlocking directorates; conflicts of interest; financial crises; universal banking; the Netherlands

\section{Introduction}

Interlocking directorates refer to a corporate governance structure whereby directors serve on the boards of multiple firms. Probably the most common type of interlock analysed in the literature is that between financial institutions and non-financial firms. Whilst the practice of establishing bank-firm interlocks is not as popular in the Netherlands today as in neighbouring Germany, ${ }^{1}$ interlocks of this kind were all the rage in this country in the early twentieth century. ${ }^{2}$ Using a case study from this small open economy, which until the Second World War had a largely unregulated financial

services sector, ${ }^{3}$ this article shows how understanding the "direction of influence" of an interlocking directorate is important in explaining how this governance structure can cause damaging conflicts of interest within universal banks, German-style financial 
institutions which offer both commercial and investment banking services. ${ }^{4}$

Economic sociologists, financial economists and economic historians have each sought to explain the phenomenon of interlocking directorates. Broad categories of reasons advanced include: ${ }^{5}(1)$ Marxist theories of financial exploitation by social elites; (2) bank-control and family-control explanations, which use agency theory to analyse banker or family networks as decision-making centres of high-finance; (3) the resourcedependency view, where interlocks are used by firms as a means of lowering information and transaction costs and gaining privileged access to markets; (4) the managerial view, where interlocks are merely expressions of prestige; and (5) the classcohesion view, where directors are all recruited from a common social group and contribute to this group's social cohesion.

Economic sociologists in particular have shown that these five explanations are not necessarily mutually exclusive; some mixture can operate side-by-side. ${ }^{6}$ Financial economists have been predominantly occupied with the task of measuring the costs and benefits of interlocks. ${ }^{7}$ They show that trade-offs exist between improved monitoring on the one hand, and various conflicts of interest on the other. Contributions to this journal have been good at quantifying interlocks between banks and non-financials in history. ${ }^{8}$ Taken together, they demonstrate that their costs and benefits vary wildly across time and by place. Elsewhere, economic historians have shown that bank-firm interlocks can in some markets significantly improve firm performance, whilst their presence in others is merely a sign of bankers' desperation. ${ }^{9}$

Aside from sociological researches that use interviews to ascertain the influence of specific interlocks, ${ }^{10}$ studies of interlocking directorates have largely provided macro-perspectives on this corporate governance structure, looking to quantify their effects at an aggregated level. Consequently, these works offer limited insight into the 
micro-level process through which interlocks can affect performance, including the impact of an interlock's direction of influence - whether firms end up managing or being managed by their ties. To understand an interlock's direction of influence, the first step in a micro-study must be to ascertain whether a firm sends or receives executives from its interlocked firms. But a catalogue of this alone is insufficient to conclusively determine direction; factors including executive remuneration, social ties, prestige, and even personality type may result in executives doing the bidding of their interlocked firms rather than that of their primary employer.

This article contributes by providing the micro-level detail necessary to understand the full implications of interlocking directorates in a case study from Dutch history. It analyses the interlock between the Rotterdamsche Bankvereeniging, a large universal bank, and Wm. H. Müller \& Co., a trading conglomerate. Referred to simply by its acronym "Robaver" in the contemporary press, this bank is one of the main predecessors of ABN AMRO, which until it was split up and sold off in 2007 was among the world's largest. ${ }^{11}$ Meanwhile, Müller \& Co. partly survives today in the form of Imtech, a technical services provider to the shipping and construction industries. ${ }^{12}$ Executives of these two concerns, which both came close to failure in the Dutch financial crisis of the $1920 \mathrm{~s}$, sat on each other's supervisory boards. The direction of influence was not obviously from the bank to the firm; the fact that this was a mutual tie alone suggests that the nature of this interlock can only be gleaned from a detailed case history.

The aim of this article is to investigate the impact of the Robaver-Müller tie on the performance of Robaver during the 1920s, to discern whether, and to what degree, the interlock was responsible for the bank's near collapse in 1924. By examining this interlock at a time of crisis, this article is able to explore the workings of a corporate 
governance structure that remain largely hidden in more stable times, when issues surrounding bank leadership tend to be largely uncontroversial in the eyes of the investing public. The method used is to construct, and then analyse, a detailed narrative of the Robaver crisis that combines contemporary press commentary with the internal records of the bank. By comparing the events of the Robaver-Müller case with those surrounding another of the bank's problematic managerial ties, and by contrasting the performance of Robaver with that of a competing bank that chose a different business policy and corporate governance structure, this article advances an "interpretive model" to explain how the direction of influence of an interlocking directorate can determine the nature and severity of conflicts of interest. ${ }^{13}$ Together, the narrative and model suggest that Robaver's newly adopted universal banking business model left it with a flat, or decentralised, organisational structure, and a lemon as a major customer whose director was able to use this structure to his own advantage. Robaver could not extract itself from Müller \& Co.'s ailing businesses unaided because the interlock made it difficult to influence the trading conglomerate's business policy. It faced no such issues, however, with one of Müller \& Co.'s rivals, with which Robaver's managerial tie was solely one-directional, from bank to firm. Meanwhile, Robaver's main competitor helped to save the bank by providing it with managerial expertise.

Other than the work of De Vries, ${ }^{14}$ little primary research has been conducted into the course of the crisis at Robaver, ${ }^{15}$ economic histories of the period mostly derive their business history insights from his work. But whilst De Vries's account forms the most complete narrative of the crisis to date, it looks at the debacle with one particular set of archival sources only: those of De Nederlandsche Bank (DNB), the Dutch's state's bank of issue. ${ }^{16}$ This perspective is invaluable in that it reveals the internal motivations and justifications for the actions of an institution that came closer to 
fulfilling the role of a modern central bank in the course of the 1920s than it had ever done before. But De Vries's sources only tell half the story. This article uses the internal management records of Robaver itself to build a new narrative from another perspective, and marries these with contemporary newspaper opinion in order to contrast this insider perspective with an outsider's view on the unfolding events. Moreover, it uses information economics, which studies how information and its revelation affect economic decisions, to interpret this narrative, to build a stylised model of the Dutch case. ${ }^{17}$

\section{The Dutch financial services sector in the early twentieth century}

Financial sectors around the world are often categorised as being either bank-based or market-based. ${ }^{18}$ There is a long tradition, epitomised by the work of Gerschenkron, which classifies Germany as being bank-based and the UK as market-based. ${ }^{19}$ The idea is that bank-based financial sectors are populated with powerful universal banks which offer the full range of financial services, whilst market-based ones contain less influential functionally-separated commercial and investment banks. Whilst in the former, banks actively hold equity stakes in non-financial firms, in the latter, nonfinancials use banks only to help place their equity on open markets, where it is bought by a diverse constituency of investors. Whilst this view has been somewhat revised by economic historians ${ }^{20}$ it nevertheless remains a useful characterisation, with countries lying somewhere between these two theoretical extremes.

The Netherlands is an interesting case in point. At the turn of the twentieth century, the country's banks played second fiddle to its capital markets. But from about 1911, and especially during the Great War, the economy started to look more like the bank-based German one. Banks replaced the prolongatie on-call money market that had dominated Dutch finance in the nineteenth century. ${ }^{21}$ A wave of bank mergers 
commenced just prior to the Great War to create sophisticated multi-branch networks with a wide portfolio of clients. ${ }^{22}$ The war itself and the post-war economic boom that followed sped up banks' move towards being universal in scope, with banks directly financing businesses with both debt and equity. The regulatory regime at the time was relatively laissez-faire: Dutch law did not prohibit commercial banks from providing investment services.

Figure 1 plots the equity-deposit ratio for the period 1917 to 1931 for Robaver, the Amsterdamsche Bank (Ambank), its main competitor, and the Big Five Dutch banks together. ${ }^{23}$ This ratio, used by Verdier to measure the characteristics of a country's banking sector, is calculated as banks' least liquid resources (capital plus reserves) divided by their most liquid ones (deposits plus savings). ${ }^{24}$ It captures the idea that commercial banks, which specialise in short-term lending, have little need for long-term equity and instead finance their activities with short-term deposits and savings.

Meanwhile, universal banks must maintain long-term resources as they hold long-term stakes in industry. Lower values indicate that commercial banks dominate; higher values indicate universal ones do. The figure suggests that Dutch banks became "more universal" in their service provision up until about 1924, and returned to their earlier nineteenth-century functional separation by the early 1930s; the financial sector became more bank-based in the decade leading up to the crisis, and returned to being marketbased following its conclusion. The structure of Robaver's balance sheet exemplifies this pattern, whilst that of rival Ambank lies at the other end of the spectrum. ${ }^{25}$

By tradition, Dutch firms employed a dual board structure on the German model, with a management board made up of directeuren (executive directors), and supervisory board of commissarissen (non-executive directors). ${ }^{26}$ Jonker uses the number of interlocks between banks and industry as an indicator of banking scope, with 
an increase in interlocks suggesting a move towards universal service provision, as banks install directors in the firms they finance. ${ }^{27}$ He finds that interlocks more than doubled in the early 1920s, from 200 interlocks in 1920 to 431 in 1923. A large part of this was due to changes at Robaver: from 20 interlocks in 1910 to 127 in 1923 . But the trend went far beyond this bank: De Jong and Röell find that, in 1923, the proportion of non-financial exchange-listed firms with no bank interlocks was 40 per cent, whilst 22 per cent had one interlock, 12 per cent had two, 8 per cent had three and 18 per cent had more than three. ${ }^{28}$ Most interlocks were between the supervisory boards of banks and non-financial firms (47 per cent), but a substantial portion involved a directeur of a bank sitting as a commissaris of a non-financial (29 per cent).

Under the stewardship of Willem Westerman, its president, Robaver was established in 1911 following the merger of the Rotterdamsche Bank - itself set up in 1863 by a group of Rotterdam businessmen - with the Deposito- en Administratiebank. ${ }^{29}$ Then, in the same year, Robaver took over the Amsterdam securities house Determeyer Weslingh \& Zoon, granting it direct access to the trading floor of Amsterdam's stock exchange, at the time a coup for a Rotterdam-based bank. Finally, the bank acquired the investment bank Labouchère Oyens \& Co. in 1913, which brought with it financial relationships with the shipping and mining subsidiaries of Müller \& Co. The centre of power at Robaver subsequently shifted north, with its new Amsterdam office becoming at least as important as its old headquarters in Rotterdam. This led to a flat organisational structure where, in many respects, offices operated de facto independently of one another. Robaver then bought up provincial banks and merged these into a single subsidiary, the Utrecht-based Nationale Bankvereeniging (Natobank), described by Westerman's son as part of a conscious expansionary strategy to emulate Germany's universal banks. ${ }^{30}$ The bank was among 
the first to mechanise its back-office, ${ }^{31}$ and, by the early 1920 s, was the country's second-largest bank by market capitalisation. ${ }^{32}$ It was also the largest casualty of the 1920s financial crisis, which, as the research in this paper uncovers, wiped out over a third of its capital and led to a serious bank run. ${ }^{33}$

The existing literature on the macro-causes of the 1920s financial crisis is dominated by the work of Jonker, ${ }^{34}$ the definitive restatement of which is found in Van Zanden's contribution to an edited volume on Dutch financial history. ${ }^{35}$ It holds that the crisis was a result of banks' over-exuberance during the Great War and immediate postwar period. Large and sustained declines in aggregate demand and prices in the early 1920s - declines which were largely due to international factors, but arguably aggravated by (expectations of) the Dutch guilder's return to pre-war gold parity - put pressure on business and thus the banking sector which it had increasingly come to rely on. In short, Dutch banks became over-exposed to the sectors of the economy that suffered most at the hands of debt-deflation. ${ }^{36}$ The next section illustrates how this macro-cause was felt at a micro-level in the case of Robaver.

\section{A narrative of the Rotterdamsche Bankvereeniging in crisis}

This is a single case study, and so no a priori and testable theoretical model of the causes of banking crises is developed. Instead this section serves to lay bare the facts of this particular crisis in a case narrative. The next section develops an interpretive model that uses information economics to understand these facts. The narrative starts in late 1922, as the signs of the problems surrounding the Robaver-Müller interlock start to become apparent to the outside world. ${ }^{37}$ It ends in late 1925, as the post-crisis clean-up operation is in full swing. In particular, the narrative highlights three aspects of the Robaver crisis: (1) the internal management difficulties experienced by the bank; (2) the impact of information asymmetries between privileged insiders and the investing public 
on the bank's fate; and (3) how interlocking directorates influenced both these aspects.

Before proceeding, this story's primary protagonists are introduced. Key players at Robaver were: (1) Willem Westerman, who became a Robaver director in 1904 and was made its president in 1908; and bank directors (2) J.P. van Tienhoven, and (3) K.P. van der Mandele, both installed by Westerman in $1910 .{ }^{38}$ Meanwhile, at Ambank, Robaver's main competitor, an important figure in the narrative is: (4) Arie J. van Hengel, one of that bank's directors. Key policymakers include: (5) Gerard Vissering, president of DNB; and (6) Hendrikus Colijn, minister of state for finances and a future prime minister. Crucial in the story is: (7) Anton G. Kröller, who succeeded his brother Willem and married into the family of the Rotterdam and Düsseldorf-based shipbrokers Müller, and from 1889 came to manage the company that was started by his father-inlaw and brother. ${ }^{39}$ By the 1920 s, Wm. H. Müller \& Co. was a commanditaire vennootschap (limited partnership) operating out of The Hague, with trading, shipbuilding and mining subsidiaries operating around the world. Robaver developed a long-standing commercial and investment banking relationship with the Müller concerns; both Westerman and Van Tienhoven sat on the supervisory board of Müller \& Co., ${ }^{40}$ whilst Kröller sat on that of Robaver from $1916 .{ }^{41}$

\section{Public suspicions and attempted solutions}

Whilst the independence of Robaver's Rotterdam and Amsterdam offices may have served the bank well in good times, conflicts between these branches started to emerge as the Dutch deflationary recession started to bite in 1922. At the weekly bank directors' meeting of 2 November 1922 there is a lively discussion about Westerman's unilateral decision to guarantee a new loan of US\$3 million to Müller \& Co. for its American cereal trading operations, arranged through Robaver's Amsterdam office. ${ }^{42}$ Y.J.H. van der Meulen, a director at the Rotterdam branch of the bank, is angry that he was only 
informed about this loan after it had already been issued and wishes that in future all directors be consulted over such large positions. He is concerned about the risks Müller $\&$ Co. is taking and their impact on the liquidity of the bank as a whole. Van Tienhoven and Van der Mandele do not appear to share Van der Meulen's grievances.

From an outsider's perspective, Robaver looks fragile. In De Kroniek, a respected fortnightly financial journal established and edited by Amsterdam-based accountant and lawyer Alexander Sternheim, concern is voiced about the latest company accounts filed by the bank. ${ }^{43}$ The article argues that it is the most vulnerable of the Big Five and speculates that its problems are caused by: (1) the downward business cycle in general; and (2) clients in shipping and mining in particular. The subtext of the second is that the bank is too close to Müller \& Co.; knowledge of the bank's long-standing mutual management interlock was in the public domain. The article criticises Robaver for failing to report its obligations towards its Natobank subsidiary, and failing to explain why the bank's profits are lower than in previous years.

Returning to a view from the inside, with another indication of management difficulties: on 11 September 1923, Westerman tells his fellow directors that he feels he has recently been left out of the loop in decisions to take on new business. The minutes read: 'If he [Westerman] had sole say, many unwanted credits would not have been issued' ${ }^{44}$ To tackle the apparent lack of coordination and communication between the bank's Rotterdam and Amsterdam offices, Westerman increases the importance of the national directiecentrale (management centre), housed at a newly-constructed branch of Robaver in The Hague - "neutral territory" halfway between the two cities. All accounting functions are moved to this single branch in an attempt to replace the bank's flat organisational structure with a more hierarchical one. 
The following month, on 4 October, considerable time is spent discussing the state of affairs at Compañia Mercantil Argentina, a free-standing company operating in Buenos Aires in which Müller \& Co. has the majority stake and on whose raad van bestuur (governing council) Westerman, Van Tienhoven, Kröller and his right-hand man, Salomon van Deventer, sit as members. The minutes record the objections of a Robaver director, Daniël Ornstein: ‘[...] every year our position worsens. Every year our losses increase and the chance of making a profit grows smaller. Does this really weigh positively against possible better returns in the long term? ${ }^{45}$ The directors decide to grant the firm a temporary loan using its Hollandsche Bank voor Zuid-Amerika subsidiary as a front, and to issue Müller \& Co. with an ultimatum to reduce the risks of its American operations. ${ }^{46}$ Willem van der Vorm, a ship-owner, coal merchant and a Robaver commissaris, ${ }^{47}$ proposes a change to the bank's statutes that would force greater cooperation between the bank's directeuren and commissarissen. It is highly probable that he was seeking a more effective way of dealing with Kröller. Westerman disagrees, as such a change may scare the public; he wishes to handle the matter more informally.

Müller \& Co. was not Robaver's only problematic client; the Nederlandsche Maatschappij voor Scheepsvaart, Handel en Nijverheid - a joint-venture between the former Dutch subsidiary of shipbrokers Furness Withy (fully in Dutch hands since 1912) and the Rotterdam merchant house R.S. Stokvis \& Zonen - is the subject of much discussion at the monthly meetings of the commissarissen, an example of which is found on 19 March $1924:{ }^{48}$ Van Tienhoven reports problems at one of that firm's subsidiary companies that places Robaver in a 'less than pleasant' position. FurnessStokvis, as the joint-venture is informally known, and which Van der Mandele helped to supervise in his capacity of commissaris,${ }^{49}$ is described shortly after this meeting in an 
article in De Kroniek as being 'naïve and fantastical' if its managers think they can solve all the concern's problems with their plan to write off 10 per cent of its share capital. $^{50}$

Despite the bank's internal worries, the publication of Robaver's annual report to shareholders in May 1924 reads on the whole upbeat, blaming the bank's 'minor problems' on the business cycle. ${ }^{51}$ The report apparently passed through the bank's layers of management with little opposition: its commissarissen approved a draft with just minor corrections at their meeting on 23 April, ${ }^{52}$ thus agreeing to a 4.5 millionguilder dividend for ordinary shareholders. Meanwhile, De Kroniek is not overly convinced with the bank's upbeat tone, suggesting that it still has to kick the habit of inflating its figures. ${ }^{53}$ The article estimates that of the bank's reported 36.5 million guilders of reserves, 20 million are in the form of equity shares in industry. With a further reported 18.4 million in shares in other financial institutions, the article argues that the reserves are not very liquid, and that their function 'as a guarantee for profitability is limited ${ }^{54}$ It questions how the bank is financing its dividend and concludes that 'only a very positive upswing in the business cycle that increases the bank's profitability can stabilise her position'. ${ }^{55}$

\section{Drastic measures}

The Robaver crisis proper plays out over the summer of 1924. On 12 May, within a month of paying a dividend, the minutes of the directors' meeting state that DNB 'shall open a special emergency overdraft account for us using promissory notes of various of our illiquid debtors as collateral' ${ }^{56}$ Further details about this account are discussed at the meeting on 15 May of the newly-formed comité - an extra layer of management created by Westerman and consisting of the bank's directeuren and a few of its commissarissen, and from which Kröller was excluded. ${ }^{57}$ One director notes that 
'rigorous steps' need to be taken in order to increase Robaver's liquidity. Featured at the top of the bank's list of problematic clients are Furness-Stokvis and Müller \& Co. The minutes reveal a consensus that a mere transfer of some of Müller \& Co.'s loans to other banks is insufficient, and that a more permanent solution needs to be found that addresses the root cause of that concern's difficulties. ${ }^{58}$

By the time of the next directors' meeting on 26 May, Van Tienhoven has visited DNB to make formal arrangements for the emergency overdraft, set at 35 million guilders. ${ }^{59}$ At this point in the negotiations the Furness-Stokvis account appears to have been left out of the equation, and the loan is designed to cover German cereal credits and the Müller \& Co. / Compañia Mercantil accounts only. Meanwhile, the bank's Rotterdam and Amsterdam offices appear to have been busy cleansing themselves of bad loans. However, one of the directors warns that they have now exhausted this avenue of increasing liquidity. The directors collectively decide that they are to inform Furness-Stokvis that they wish to cease any further dealings with that company.

Two days later, during a meeting of the comité on 28 May, Robaver's managers plan a drastic course of action aimed at restoring public confidence in the bank. An annex to the meeting's minutes, marked as 'highly confidential', discusses how, as a consequence of adverse media attention, mistrust in the bank has reached such heights that it has caused incredible downward pressure on Robaver's share price, which in time could have very serious consequences. ${ }^{60}$ Figure 2 shows that the share price - which until May remained at a very stable level, trading almost at par - jumped downwards by about five percentage points.

Westerman opines to his fellow directors that the public, and especially financial professionals, blame him and Van Tienhoven personally for the bank's state of affairs. 
Van Tienhoven then informs the directors that he has decided to resign from his post to act as a 'peace offering' to the public. Westerman's plan is to call an Extraordinary General Meeting (EGM) of shareholders in August, at which the position of bank president will be abolished. Instead he proposes that the bank should be led by a new body, a raad van toezicht (overseeing council). Westerman would then swap his current position for that of joint president of the commissarissen and the raad. In Westerman's opinion, the key advantage to the status quo is that the bank would be led by consensus: Westerman would have members of the raad constantly around him for advice. However, there is some discussion as to whether the public would perceive it in this way, as essentially the same individuals would remain in charge, albeit in different guises. Other directors are worried that the dual resignation would have the opposite effect to that intended, that such an announcement could lead to further adverse fluctuations in Robaver's share price.

Westerman presents his plan, now agreed upon by his colleague directors, at a specially convened meeting of all directeuren and commissarissen on 5 June. ${ }^{61} \mathrm{He}$ opines to those present, among whom Kröller, that 'recently he is under the impression that it is not going well with the bank, especially in Amsterdam'. The bank's directeuren inform its commissarissen that Robaver has been forced to buy up 2.6 million guilders of its own shares in order to stabilise the price, which explains the periods of unusual price stability observed in Figure 2. They argue, and the commissarissen appear to agree, that Westerman's plan should be implemented, as further share price support is unsustainable. A week later, at the 12 June comité meeting, the minutes read that the bank's liquidity still 'leaves something to be desired' ${ }^{62}$ Müller \& Co. and Furness-Stokvis are again fingered as the culprits. Details of Van Tienhoven's resignation, which is planned for 15 June, are outlined. There is 
discussion of a rumour circulating at the stock exchange that Westerman is the one to be resigning, which they plan to 'positively deny' when dealing with the press.

\section{Announcement, crash and run}

On 16 June 1924 De Kroniek publishes the news of Van Tienhoven's resignation. The accompanying comment praises his time at Robaver: ${ }^{63}$

The change in position of Mr Van Tienhoven is undoubtedly one of the most important occurrences in the area of banking in recent times. From 1912, and especially during the war, Mr Van Tienhoven has been the most important driving force behind the bank merger movement and in the finance of domestic industry.

However, Van Tienhoven's resignation proves insufficient to calm markets. Two weeks later, on 1 July 1924, DNB makes the following communiqué available to the press: $:^{64}$

The various rumours concerning the financial position of the Rotterdamsche Bankvereeniging have motivated the directors of this institution to turn to the president of De Nederlandsche Bank, whom they are providing with all materials regarding the bank's liquidity. Following an examination of the supplied materials, the president of De Nederlandsche Bank has proclaimed that he is prepared to work with the directors of the Rotterdamsche Bankvereeniging, and if necessary to maintain her liquidity.

There is a strange absence of records of directors meetings in the immediate build-up to the publication of the above communiqué. From De Vries's account of the Robaver crisis, which makes use of the personal correspondence of some of the bank's directors deposited in DNB's archives, it appears that these meetings were held in private at the homes of directors and remained unminuted. ${ }^{65}$ Interestingly, De Vries notes that a group of Robaver directors initially approached DNB president Vissering with news of the bank's problems without Westerman's knowledge. Later, on 30 June, 
and now in the presence of Westerman, Vissering arranges 50 million guilders of support for Robaver, under guarantee from finance minister Colijn. De Vries argues that Colijn does not initially wish to support Robaver's share price, but is later convinced to do so by Westerman. ${ }^{66}$

Whilst the public appears to remain in the dark about the goings on in the finance ministry, ${ }^{67}$ Westerman explains in detail the chain of events that led to DNB's intervention, and the published communiqué, at the next meeting of the commissarissen on 10 July: ${ }^{68}$

Towards the end of June the supply of our shares was increased in such quantities, that the directors did not dare to buy them up. After a discussion with the Comité, they [the directors] decided to call in help from De Nederlandsche Bank, which declared a willingness to help in principle, but required further discussion with the government before a firm commitment could be made. [...] The Minister [Colijn] declared that it was in the interest of the nation to avoid a catastrophe, and that he was therefore willing to support the Rotterdamsche Bankvereeniging with a substantial sum. [...] there was talk with De Nederlandsche Bank about a fl.100,000,000 support, but De Nederlandsche Bank is to limit her involvement to fl.50,000,000 for the meantime, and that support for the share price, about which the Minister had shown an interest, was not on the table. In return De Nederlandsche Bank demanded the publication of a communiqué in the newspapers, which our directors conceded to under pressure. This communiqué was published in the morning papers of Tuesday 2 July, with the well-known disastrous consequences.

The disastrous consequences in question were: (1) a crash in Robaver's share price (see Figure 2); and (2) what appears to be a sizable run on the bank's branch network. A meeting of the comité held just prior to that of the commissarissen reveals that in the period 28 June to 5 July the bank's depositors withdrew money to the tune of 42.4 million guilders, bringing reserves to a new total of 96.6 million - a drop of some 30 per cent. ${ }^{69}$ However, a fully-blown run on the bank, depleting all its resources, was 
apparently avoided: 'At the current moment withdrawals appear to have come to an end ${ }^{70}$ The government provided 10 million guilders with which to stabilise the share price because DNB refused to do so itself. But Colijn did not initially want to be seen openly to have lent support to Robaver and therefore used an intermediary, the firm Van Loon \& Co. ${ }^{71}$ Later in the same meeting, the minutes record that DNB wishes Robaver to appoint a 'competent Dutchman of standing' as a new director who would then help reassure the public.

\section{Post-mortems and purges}

On 15 July, De Kroniek publishes a detailed report on the Robaver crisis addressing four issues: ${ }^{72}$ (1) what occurred in the two weeks following the communiqué; (2) the possible cause of the crisis; (3) how Robaver can regain investors' trust; and (4) the role of DNB. These are summarised as follows. (1) In the period since the communiqué, the article notes that 'the panicky reaction has disappeared completely and has made way for a period of calm, but without any clarification about the factual events'. It argues that the wording of the communiqué was probably too negative and that the liquidity was probably never in danger. (2) Robaver was probably overvalued as a result of the 25 million guilders worth of new shares that were issued by the bank in 1919; its author points his finger at the expansionary policy of the bank. (3) The only way in which Robaver can regain the public's trust is to publish a full and frank admission of its mistakes. Robaver also needs a new banker in charge who can be trusted, and a new set of commissarissen. (4) The article notes that the firm Van Loon \& Co. bought up the shares that stabilised the concern's price at 89 per cent of par. Unaware of the government's involvement, the newspaper speculates that this was probably carried out under the guarantee of DNB, a course of action about which its editor is deeply concerned. 
On 17 September, a secret draft restructuring plan is presented to Robaver's commissarissen..$^{73}$ It proposes to reduce the capitalisation of Robaver by swapping 25 million guilders worth of shares for amortisation certificates against future profits. The source of the shares is as follows: 15 million from the state-backed syndicate that was formed to support the share price during the intervention, and the 10 million worth of Robaver shares held by Müller \& Co.; Kröller's managerial influence over Robaver before the crisis appears to have been accompanied by not insubstantial crossownership, albeit with murky provenance. ${ }^{74}$ This 25 million guilder swap is to be used to write off bad debt (21 million) and buy back additional Robaver shares (4 million). A further 3 million of securities and property are to be covered by profits, and 15 million guilders worth of guarantees towards its subsidiary banks (including Natobank) are to come from a newly-created special reserve. De Vries's account of the crisis argues that DNB and the Dutch state were very involved in the drafting of this restructuring plan. ${ }^{75}$ This is supported by the minutes of the comité meeting held immediately prior to the 17 September commissarissen meeting, at which a dialogue between Robaver and DNB is recounted. ${ }^{76}$ Despite Van der Mandele's pleas, Furness-Stokvis, the firm he helps to supervise, is not incorporated into this restructuring plan.

The finalised details of this restructuring plan, minus the identities of its financial backers, are published only a month later in De Kroniek. ${ }^{77}$ The press release also informs shareholders that the position of president is to be abolished, that Westerman is to be redeployed as a commissaris and that Van Hengel, a director at Ambank, is to be made gedelegeerd commissaris (de facto caretaker president). De Kroniek addresses three issues concerning Robaver's news: (1) the continued lack of clarity concerning the crisis; (2) the possibility of harmful collusion in the banking sector; and (3) the position of Westerman. These are addressed as follows. (1) The 
article argues that the public is none the wiser as to why the crisis occurred in the first place. The press release does not reveal the origin of the 25 million to be used to reduce the bank's capitalisation, only that it is from 'friendly hands'. (2) The choice of Van Hengel as caretaker president concerns De Kroniek because he is from a competing bank where he plans to maintain his position, a managerial tie the newspaper's editor views as potentially dangerous for customers. (3) The article notes that if Westerman is truly responsible for the crisis, then he should be removed from the bank's management completely, and not simply be given a new position. ${ }^{78}$

By the time of the next issue of De Kroniek, EGMs have taken place at both Robaver and Ambank to ratify the restructuring plans and staff changes. The article argues that six questions concerning the role of DNB need answering before the sector can return to normality: ${ }^{79}$ (1) Does DNB act objectively? (2) Has it carried out any additional interventions, other than ascertaining the liquidity of Robaver, outside of its traditional mandate? (3) What was the motivation behind the (now infamous) communiqué if, as all parties now maintain, the liquidity of Robaver was never in danger? (4) Why is DNB concerning itself with the internal matters of private banks? (5) Has DNB acted in the public interest? And finally, (6) can the banking sector continue to operate without any new regulations?

\section{Long-term solutions}

Van Hengel stayed on at Robaver until 1927, after which he returned to Ambank. During his reign, three wide-sweeping reforms were implemented at the bank: (1) he paved the way for the incorporation of the Natobank subsidiary into Robaver; (2) he oversaw a comprehensive change of personnel on the bank's supervisory board; and (3) he led the restructuring of bad debt. Van Hengel's changes were conducted not without opposition from Robaver's existing team of directors, ${ }^{80}$ or its major clients. 
Especially Van Hengel's efforts to restructure the debt of the Müller \& Co. conglomerate were important for the bank's long-run stability. His close involvement is evident from his collected personal correspondence with Kröller. ${ }^{81}$ On 20 December 1924, he wrote the first in a series of letters to the Müller \& Co. chairman advocating that he needed to divest his non-core business ventures, employ professional directors and stop using borrowed money as working capital. Kröller proves to be a very difficult person to work with, however; on numerous occasions the two are at loggerheads about the best way to solve the company's problems and reduce Robaver's exposure to his concerns. On 28 March 1925, Kröller writes that his business's woes are merely due to the bad economic climate and that its bank loans are on a sounder footing than Van Hengel's letters insinuate. Kröller's strategy appears to have been to keep Robaver in the dark about his activities until they go awry; Van Hengel's constant demands for information about various Müller \& Co. accounts stay unanswered, but when Kröller needs additional funds to keep a particular business venture alive - such as his ill-fated English \& Dutch Meat Company investment in the summer of 1925, a company which later goes bust ${ }^{82}-$ he writes to Van Hengel for new loans as if it is "business as usual". Van Hengel works with Müller \& Co. to produce some figures on the concern's health, but Westerman, who in late 1925 acts as a go-between, argues for their publication to be delayed, as information about the true state of affairs could make investors jumpy; he opines on 11 December that if this information were revealed to investors, that they may draw the conclusion that in the event all Kröller-managed concerns had to be liquidated, then this would result in financial ruin for Robaver. ${ }^{83}$ Van Hengel's attempt to install new managers at Müller \& Co. subdivisions was constantly blocked by Kröller, who on 18 December 1925 writes that because he was personally responsible for building up the "Müller Empire", only he knew how to lead it 
effectively. Kröller even threatens to switch to a competing bank, the Nederlandsche Indische Handelsbank. But his attempt to use this as leverage to improve his chances with Robaver proves unsuccessful. Kröller appears to have lost his influence over Robaver; government intervention, new bank managers and the dilution of his Robaver stake reversed the direction of influence of the Robaver-Müller tie.

Van Hengel was eventually successful at unwinding Robaver's position in Müller \& Co. by placing the viable parts of the concern in a new business vehicle, and keeping its shares as collateral on its loans. Then, in 1927, Kröller was able to repay

these loans by selling his Swedish mining investments. ${ }^{84}$ But the firm remained weak and suffered greatly in the early 1930s; Kröller was forced from his post in 1931. Meanwhile, Furness-Stokvis, the other company that was constantly fingered by Robaver's managers as a cause of the bank's woes, was bankrupted by 1936 and subsequently liquidated. ${ }^{85}$

\section{An interpretive model of the crisis}

The narrative of the previous section shows that Robaver's strategy of expanding into the business of universal banking had left it with a flat organisational structure that was ill-designed for managers to effectively steer it through a period of debt-deflation. Whilst a universal business model does not as a rule lead to decentralised management, nor necessarily an increased use of interlocking directorates, it did in the Dutch case. Different branches operated almost independently of one another, with various directors building personal empires of interlocks, a structure that exposed the bank to the abuses of a large client with which it shared managers. Unlike other problematic customers, the Müller \& Co. positions could not be easily unwound because of the great power that Kröller, that firm's director, held over Robaver's managers and the lack of influence Robaver's managers had over Müller \& Co., despite, or because of, their mutual 
managerial tie. Robaver became so intertwined with Müller \& Co. that Kröller was able to use it as his private piggy bank, receiving ever-larger loans for ill-advised foreign ventures. The Robaver-Müller tie can at this stage be characterised by the resourcedependency view of interlocks, ${ }^{86}$ where Kröller uses his position to receive financing that he would never have secured elsewhere. A similarly problematic client in the same line of business, but with which the direction of influence went the other way, did not enjoy this privileged treatment; the bank was able to cut its ties with Furness-Stokvis relatively rapidly.

Recognising that there were conflicts of interest between the bank and the firm, the bank's management deliberately and systematically covered up what it was doing by obfuscating where Kröller's money was coming from. Top management tried to quell the various rumours about the state of the bank's finances, first by restructuring the way executive decisions were made by strengthening the role of the new management centre in The Hague, subsequently by excluding Kröller from the decision-making process, then by artificially supporting Robaver's share price, and finally by turning to DNB for emergency assistance. DNB itself secretly turned to the finance ministry for help, worried that it could not bear Robaver's burden on its own, or scared that supporting it would eat away at its profits - the Netherland's bank of issue had itself private shareholders to answer to. When the public caught wind of what was happening, a stock crash and bank run ensued, which no amount of internal management reshuffling could stop. In order to solve the crisis, it took existing managers to be purged and replaced with outsiders, the bank's position in Müller \& Co. to be unwound and DNB to make absolutely clear to the public that it would not abandon the bank. Signs of Kröller's earlier power over the bank were evident from the way in which its new caretaker president faced difficulties in dealing with the trading conglomerate in the aftermath of 
the crisis. But the Robaver-Müller tie's direction of influence was eventually reversed, in no small part due to government intervention. This intervention changed the Robaver-Müller tie from a resource-dependency relationship into a bank-control one, ${ }^{87}$ where the bank was able to use its interlocking directorate to extract itself financially from the trading conglomerate.

Whilst the interlock may have been the necessary condition for the 1924 crisis, it was not a sufficient one. Robaver's problems were first and foremost due to its earlieradopted universal banking policy, the interlock and decentralised management structure being consequences of this policy. There is an extensive literature on the costs and benefits of the universal banking, a type of business model also known as "relationship banking". The existence of a trade-off between banking scope - the choice between universal and functionally-separated banking - and financial stability is contentious. ${ }^{88}$ Universal banks are often touted as being able to reduce the problems of asymmetric information suffered by functionally-separated banks. ${ }^{89}$ However, their simultaneous presence in both the commercial and investment banking markets potentially creates damaging conflicts of interest. Universal banks are recognised to benefit from highly diversified portfolios. However, they may be less versatile during an economic downturn as they are geared towards the long-term and may struggle to meet depositor demand.

An interpretive model describes how Robaver's universal banking policy, and resulting managerial structure, could have been responsible for its problems. Boot and Thakor provide an appropriate starting point. ${ }^{90}$ They posit that firms face a trade-off between: (1) bank financing, where banks have the ability to better determine moral hazard, the tendency to take undue risk if this risk-taking can be hidden; and (2) capital market financing, where firms have the ability to adapt to performance information 
through prices. There exists some quality cut-off point, below which borrowers approach commercial banks - a firm's moral hazard is too severe and requires bank monitoring - and above which they approach investment banks for access to capital markets. Whilst functionally-separated investment banks can choose their portfolios solely based on the costs and benefits of capital market variables, universal banks, which provide both services "under one roof", are able to internalise any potential downside risks through their commercial banking arms. Conflicts of interest arise here because the principal in one half of the business acts as an agent in the other half. There may be a tendency for banks to positively select risky customers, due to the moral hazard of being able to cover any losses out of their depositors' purse. Recognising this conflict, an adverse selection problem may arise; commercial clients with less risky businesses choose to exit the market à la Akerlof's "market for lemons", 91 leaving only high-risk crisis-prone clients behind.

Adding the practice of interlocking directorates to the Boot and Thakor framework, sharing managers with a bank in return for access to financing may reduce moral hazard problems, but it also makes it more costly for firms to end a banking relationship in the future, as the bank's directors exert influence over the firm's financing decisions. Clients with less risky businesses may therefore never seek out such ties in the first place, choosing alternative sources of finance that do not come with managerial ties. The net result is that banks that choose to adopt interlocks may be left with a portfolio of lemons; the problem suffered by universal banks is amplified when combined with interlocking directorates. Comparing Robaver with Ambank illustrates this point. Whilst the former enthusiastically adopted universal banking with interlocks, the latter was more reluctant. Whilst the former required a government bailout in 1924 , 
the latter not only survived the crisis unscathed, but also provided the former with the managerial expertise necessary to resolve its troubles.

Finally, adding direction of influence to this interpretive model helps explain why the Robaver-Müller tie was more damaging that the Robaver-Furness-Stokvis one. After a period in which "good" firms actively choose not to employ the services of a universal bank which adopts interlocks, and combined with that bank's leadership managing to extract itself financially from those crisis-stricken firms over which it has some managerial influence, the bank is ultimately left only with the worst kind of clients: ones with which it has an interlock with a direction of influence running from the firm to the bank, where the bank does the firm's bidding, whatever the cost. In summary, the use of interlocking directorates as a corporate governance structure ultimately led to financial instability in the Dutch case.

Explanations of financial crises arising from information economics focus on the differences in information available to different parties in a financial contract. ${ }^{92}$ Adverse selection problems arise because lenders cannot distinguish between borrowers and end up setting a price that attracts only the risky. Moral hazard problems arise because borrowers have an incentive to engage in risky activities as lenders cannot easily ascertain their effort. Banks exist to reduce these problems, but are not always able to do so, such as in situations in which they have little ability to punish risky customers. In the case of Furness-Stokvis, the direction of influence was such that Robaver was easily able to punish its client by ending its financial relationship with the ailing concern. The direction of the Robaver-Müller tie meant that the bank's customer was also its manager; punishing the conglomerate for bad behaviour proved difficult.

In a deflationary cycle like that experienced in the Netherlands in the 1920 s, wealth is redistributed from debtor to creditor, increasing the real value of debt and 
reducing borrowers' net worth. Bankers, very aware of this problem, must reduce their exposure to risky customers and absolutely cannot be seen to increase it further out of fear that they will be identified as a weak player. As the Robaver case shows, if the direction of influence of an interlock prevents them from achieving this, then they may have to resort to hiding their problems from the world. But as information leaks out that a bank's interlock is preventing it from restructuring, or even just a rumour that this might be the case, the bank may have to resort to drastic measures to resolve its problems. A crisis may become self-fulfilling; ${ }^{93}$ by acknowledging that it has sought

outside help, a bank run may ensue as the panicked reaction of some depositors makes it rational for others to withdraw their deposits. The effect of the DNB communiqué must be seen in this light; the June 1924 run on Robaver's branch network may never have occurred had it not been published.

\section{Conclusion}

The current literature on interlocking directorates is very good at counting and quantifying their costs and benefits. The case study approach used here complements this with a micro-perspective on conflicts of interest arising from bank-firm interlocks. A new historical narrative informs an interpretive model that uses economic theory to explain the conduct of bankers and their customers. It argues that the direction of influence of interlocks between universal banks and their clients greatly affects their ability to weather a financial crisis. Whilst perhaps not a sufficient condition for the 1924 crisis episode, the Robaver-Müller interlock was a necessary one; the managerial tie created the conditions that drove the bank to take the drastic measures that ultimately led to its near-collapse. The interlock resulted in conflicts of interest that required state intervention to resolve - intervention so exotic in nature that the Netherlands' bank of issue cannot be deemed to be a modern central bank in this period. This case also 
illustrates that a bank's managerial structure has important consequences: had Robaver been more centralised, more hierarchical, then the abuses of Kröller may never have been possible.

Dutch banks largely abandoned their universal banking business model following the Dutch financial crisis of the 1920s. The use of interlocking directorates as a corporate governance structure was consequently wound back. Dutch banks were sufficiently restructured by the time of the Great Depression to largely avoid further upsets. The Robaver-Müller interlock and its very public consequences may have played a part in this change of strategy. Bankers may have recognised that the potential direction of influence that came with some interlocks failed to guarantee business longevity.

\section{References}

Akerlof, George. 'The Market for Lemons: Qualitative Uncertainty and the Market Mechanism'. Quarterly Journal of Economics 84 (1970): 488-500.

Arias, L.M. 'Analytic Narratives: The Method'. In International Encyclopedia of Political Science, Ed. B. Badie, D. Berg-Schlosser and L. Morlino, 71-72. Thousand Oaks: SAGE Publications, 2011.

Benston, G.J. 'Universal Banking'. The Journal of Economic Perspectives 8 (1994): 121-143.

Bini Smaghi, L. 'Commentary: Conflicts of Interest and the Financial Crisis'. International Finance 12 (2009): 93-106.

Boot, A.W.A. 'Relationship Banking: What Do We Know?' Journal of Financial Intermediation 9 (2000): 7-25.

Boot, A.W.A., and Thakor, A.V. 'Banking Scope and Financial Innovation'. The Review of Financial Studies 10 (1997): 1099-1131.

Boyd, B. 'Corporate Linkages and Organizational Environment: A Test of the Resource Dependence Model'. Strategic Management Journal 11 (1990): 419-430. 
Colvin, C.L. 'Religion, Competition and Liability: Dutch Cooperative Banking in Crisis, 1919-1927'. PhD Dissertation, London School of Economics and Political Science, 2011.

Crockett, A., Harris, T., Mishkin, F.S., and White, E.W. Conflicts of Interest in the Financial Services Industry: What Should We Do About Them? Geneva and London: International Center for Monetary and Banking Studies and Centre for Economic Policy Research, 2004.

Davis, G.F., and Mizruchi, M.S. 'The Money Center Cannot Hold: Commercial Banks and the U.S. System of Corporate Governance'. Administrative Science Quarterly 44 (1999): 215-239.

De Jong, A., and Röell, A. (2005). 'Financing and Control in the Netherlands'. In $A$ History of Corporate Governance Around the World, Ed. R.K. Mork, 467-506. Chicago: University of Chicago Press, 2010.

De Jong, A., DeJong, D.V., Mertens, G., and Wasley, C.E. 'The Role of SelfRegulation in Corporate Governance: Evidence and Implications from the Netherlands'. Journal of Corporate Finance 11 (2005): 473-503.

De Long, B.J. 'Did J.P. Morgan's Men Add Value? An Economist's Perspective on Financial Capitalism'. In Inside Business Enterprise: Historical Perspectives on the Use of Information, Ed. P. Temin, 205-236. Chicago: University of Chicago Press, 1991.

Deloof, M., Roggeman, A., and Van Overvelt, W. 'Bank Affiliations and Corporate Dividend Policy in Pre-World War I Belgium'. Business History 52 (2010): 590616.

Demirgüç-Kunt, A., and Maksimovic, V. 'Funding Growth in Bank-Based and MarketBased Financial Fystems: Evidence from Firm-Level Data'. Journal of Financial Economics 65 (2002): 337-363.

De Vries, J. Geschiedenis van de Nederlandsche Bank: Visserings Tijdvak 1914-1931. Vol. 5, Part 1. Amsterdam: NIBE, 1989.

De Vries, J., Vroom, W., and De Graaf, T. Worldwide Banking: ABN AMRO Bank 1824-1999. Amsterdam: ABN AMRO, 1999.

De Wit, O., and Van den Ende, J. 'The Emergence of a New Regime: Business Management and Office Mechanisation in the Dutch Financial Sector in the 1920s'. Business History 42 (2000): 87-118. 
Diamond, D.W., and Dybvig, P.H. 'Bank Runs, Deposit Insurance, and Liquidity'. Journal of Political Economy 91 (1983): 401-419.

Dittmann, I., Maug, E., and Schneider, C. 'Bankers on the Boards of German Firms: What They Do, What They Are Worth, and Why They Are (Still) There'. Review of Finance 14 (2010): 35-71.

Edwards, J., and Ogilvie, S. 'Universal Banks and German Industrialization: A Reappraisal'. Economic History Review 49 (1996): 427-446.

Fisher, I. 'The Debt-Deflation Theory of Great Depressions'. Econometrica 1 (1933): 337-338.

Flyvbjerg, B. 'Five Misunderstandings about Case Study Research'. Qualitative Enquiry 12 (2006): 219-245.

Fohlin, C. 'The Rise of Interlocking Directorates in Imperial Germany'. Economic History Review 52 (1999): 307-333.

Fohlin, C. Finance Capitalism and Germany's Rise to Industrial Power. Cambridge: Cambridge University Press, 2007.

Gerschenkron, A. Economic Backwardness in Historical Perspective: A Book of Essays. Cambridge MA: Harvard University Press, 1962.

Heldring, E. Herinneringen en Dagboek van Ernst Heldring 1871-1954. Ed. J. de Vries, Vol. 1. Groningen: Wolters-Noordhoff, 1970.

Imtech. 150 Years of Technology \& Entrepreneurship 1860-2010: The History of the European Technical Services Provider Imtech N.V. Gouda: Imtech, 2010.

Jonker, J. 'Sinecures or Sinews of Power? Interlocking Directorship and Bank-Industry Relations in the Netherlands, 1910-1940'. Economic and Social History in the Netherlands 3 (1991): 119-132.

Jonker, J. 'Spoilt for Choice? Banking Concentration and the Structure of the Dutch Banking Market, 1900-1940'. In The Evolution of Financial Institutions and Markets in Twentieth-Tentury Europe, Eds. Y. Cassis, G.D. Feldman and U. Olsson, 187-208. Aldershot: Scholar Press, 1995.

Jonker, J. 'Between Private Responsibility and Public Duty. The Origins of Bank Monitoring in the Netherlands, 1860-1930'. Financial History Review 3 (1996): 139-152.

Jonker, J. 'Competing in Tandem: Securities Markets and Commercial Banking Patterns in Europe during the Nineteenth Century. In The Origins of National Financial 
Systems: Alexander Gerschenkron Reconsidered, eds. D.J. Forsyth and D. Verdier, 64-86. New York: Routledge, 2002.

Jonker, J. 'Kröller, Anthony George (1862-1941)'. In Biografisch Woordenboek van Nederland (2012),

http://www.historici.nl/Onderzoek/Projecten/BWN/lemmata/bwn6/kroeller

Jonker, J., and Van Zanden, J.L. 'Method in the Madness? Banking Crises Between the Wars, an International Comparison. In Banking, Currency, and Finance in Europe Between the Wars, Ed. C.H. Feinstein, 77-93. Oxford: Clarendon Press, 1995.

Kroszner, R.S., and Strahan, P.E. 'Bankers on Boards: Monitoring, Conflicts of Interest, and Lender Liability'. Journal of Financial Economics 62 (2001): 415-452.

Lichtenauer, W.F. 'Vorm, Willem van der (1873-1957)'. In Biografisch Woordenboek van Nederland (2012),

http://www.historici.nl/Onderzoek/Projecten/BWN/lemmata/bwn1/vormw

Mishkin, F.S. 'Asymmetric Information and Financial Crises: A Historical Perspective'. In Financial markets and financial crises, Ed. R.G. Hubbard, 69-108. Chicago: University of Chicago Press, 1991.

Mizruchi, M.S. 'What Do Interlocks Do? An Analysis, Critique, and Assessment of Research on Interlocking Directorates'. Annual Review of Sociology 22 (1996): 271-298.

Newton, L. 'Regional Bank-Industry Relations during the Mid-Nineteenth Century: Links between Bankers and Manufacturing in Sheffield, c.1850 to c.1885'. Business History 38 (1996): 64-83.

Petimezas, A.Q. 'Icarus van het Nederlandse Bankwezen. De Rotterdamsche Bankvereeniging 1905-1925: Groei en Val van Nederlands Grootste Bank'. Master's Thesis, Rijksuniversiteit Gronigen, 2011.

Rotterdamsche Bankvereeniging. Annual Reports to Shareholders, 1911-1929.

Rovers, E. De Eeuwigheid Verzameld. Helene Kröller-Müller (1869-1939). Amsterdam: Uitgeverij Prometheus/Bert Bakker, 2010.

Scott, J. 'Theoretical Framework and Research Design'. In Networks of Corporate Power: A Comparative Analysis of Ten Countries, Eds. F.N. Stokman, R. Ziegler and J. Scott, 1-19. Cambridge: Polity Press, 1985.

Stichting voor Economisch Onderzoek der Universiteit van Amsterdam. 'Eerste Rapport: Geldscheppende Instellingen en Spaarbanken. In Onderzoek in 
Opdracht van De Nederlandsche Bank N.V. naar Balansstructuur en

Ontwikkelingen van de Financiële Instellingen in Nederland sedert 1900.

Amsterdam: University of Amsterdam, 1972.

Tomka, B. Interlocking Directorates of Banks and Industrial Companies in Hungary at the Beginning of the Twentieth Century'. Business History 43 (2001): 25-42.

Tweede Kamer. 'Mededeeling van Ingekomen Stukken'. Handelingen der StatenGeneraal. 63rd meeting, 29 March (1927): 1863.

Tweede Kamer. 'Memorie van Antwoord'. Handelingen der Staten-Generaal. Bijlagen, 291 (1927): 7-9.

Verdier, D. 'Explaining Cross-National Variations in Universal Banking in NineteenthCentury Europe, North America, and Australasia., In The Origins of National Financial Systems: Alexander Gerschenkron Reconsidered, Eds. D.J. Forsyth and D. Verdier, 23-42. New York: Routledge, 2002.

Westerman, W.M. De Concentratie in het Bankwezen: Een Bijdrage tot de Kennis der Economische Ontwikkeling van Onzen Tijd. The Hague: Martinus Nijhoff, 1920. Van Oss Effectenboek 1919. Vol. 1 (Binnenland). The Hague: S.F. van Oss, 1920.

Van Zanden, J.L. 'Old Rules, New Conditions, 1914-1940'. In A Financial History of the Netherlands, Eds. M. 't Hart, J. Jonker, and J.L. van Zanden, 124-151. Cambridge: Cambridge University Press, 1997.

${ }^{1}$ De Jong et al., 'The Role'; Dittmann et al., 'Bankers on the Boards'.

2 Jonker, 'Sinecures or Sinews'; De Jong and Röell, 'Financing and Control'.

${ }^{3}$ Jonker, 'Spoilt for Choice?'.

${ }^{4}$ See Crockett et al., Conflicts of Interest, for a wider discussion of the various conflicts of interest experienced by banks, and Bini Smaghi, 'Commentary', for a note on this topic in the context of the recent financial crisis.

${ }^{5}$ Scott, 'Theoretical Framework'.

${ }^{6}$ Boyd, 'Corporate Linkages', analyses a sample of US firms in 1980 to differentiate between the resource-dependency and managerial views of interlocks, and finds that successful firms fit the former rather than the latter, using interlocks to manage uncertainty. Davis and Mizruchi, 'The Money Center', argue that the centrality of bankers in corporate networks fell significantly in the US over the 1980s as major corporations moved away 
from bank finance and towards market finance; firms had little need for banker representation on their boards, and visa versa.

${ }^{7}$ Using data on US corporate networks in the early 1990s, Kroszner and Strahan, 'Bankers on Boards', find that bankers tend to sit on the boards of large, stable firms that do not rely on short-term debt; firms with highly volatile asset ratios shy away from having bankers on their board because of conflicts of interest. Dittmann et al., 'Bankers on the Boards', find that bankers sit on the boards of non-financials to promote their own business and can help firms obtain funding in difficult times. But their econometric analysis of German interlocks between 1994 and 2005 also shows that having bankers on boards reduces the value of non-financials.

${ }^{8}$ Newton, 'Regional Bank-Industry Relations', shows that Sheffield's bankers in the midnineteenth century were able to preserve impartiality when dealing with the manufacturers they shared managers with; Tomka, 'Interlocking Directorates', argues that information incentives for interlocks were irrelevant for one Hungarian bank in the early twentieth century; and Deloof et al., 'Bank Affiliations', quantify the benefits of interlocks for investor returns for the case of Belgium at the turn of the century.

${ }^{9}$ De Long, 'Did J.P Morgan's Men', finds that in the early 1910s the presence of a J.P. Morgan partner on the board added 15 per cent to the market value of a firm. In contrast, Jonker, 'Sinecures or Sinews', argues for a reversed causality, that bank-firm managerial ties became popular in the Netherlands because banks became worried that booming industry would leave them behind. Fohlin, 'The Rise', finds scant evidence that interlocks improved monitoring or signalled quality for the case of Imperial Germany and argues instead that interlocks arose there only at a time of dispersed corporate ownership at the tail end of industrialisation.

${ }^{10}$ See Mizruchi, 'What do Interlocks Do?', for a discussion of such works.

${ }^{11}$ In 2005, two years before the bank was the subject of an acquisition battle, Global Finance ranked $A B N A M R O$ as the 16th biggest bank in the world. http://www.gfmag.com/archives/60-60-october-2005/1648-award-winners--the-worldsbiggest-banks-2005.html

${ }^{12}$ Imtech, 150 Years.

${ }^{13}$ Whilst being similar in terms of implied methodology, the term "interpretive model" is used here instead of "analytic narrative" because in economic history the latter has come to be narrowly associated with the use of formal rather than verbal theory, and the use of game theory rather than other rational choice theory (Arias, 'Analytic Narratives').

${ }^{14}$ De Vries, Geschiedenis, 243-257. 
${ }^{15}$ Petimezas, 'Icarus', a Master's project on the history of Robaver largely completed after the current article was written, is a new work that also covers the crisis period. Petizimas uses the same archival sources that are used in this article, but does not focus on the crisis period, or the workings of the Robaver-Müller interlock.

${ }^{16}$ DNB was a private institution listed on the Amsterdam stock exchange. It had no formal oversight role, and had no de facto or de jure duty as a lender-of-last-resort (Jonker, 'Between Private Responsibility'). Prior to the Great War, DNB had influenced the financial services sector only by example.

${ }^{17}$ Flyvbjerg, 'Five Misunderstandings', argues that summarising and theorising narratives is undesirable, that case studies should be self-contained. The approach taken here - to separate the narrative from the interpretation - facilitates such critics to develop their own answers to their personal "so what?" questions. Given the evidence presented, the interpretive model is one plausible interpretation, a contextualised theory of causality using the framework of information economics.

${ }^{18}$ See, for example, Demirgüç-Kunt and Maksimovic, 'Funding Growth'.

${ }^{19}$ Gerschenkron, Economic Backwardness.

${ }^{20}$ Edwards and Ogilvie, 'Universal Banks', and Fohlin, Finance Capitalism, demonstrate that Germany's financial sector was far more complicated than Gerschenkron's characterisation.

${ }^{21}$ Jonker, 'Competing in Tandem'.

${ }^{22}$ Jonker, 'Spoilt for Choice?'.

${ }^{23}$ The Big Five constitutes: Ambank, Incasso-Bank, Nederlandsche Handel Maatschappij, Robaver and Twentsche Bank. All five eventually merged into what is now ABN AMRO (De Vries et al., Worldwide Banking).

${ }^{24}$ Verdier, 'Explaining Cross-National Variations'.

${ }^{25}$ The zeal of Robaver's managers to adopt a universal business model with interlocking directorates was more extreme than that of managers at competing banks, and so this case may be a deviant rather than a critical one (Flyvbjerg, 'Five Misunderstandings'). However, outliers too need explaining - especially if their impact on society proves to be large.

${ }^{26}$ Commissarissen were normally appointed at shareholders' meetings on the advice of directeuren (De Jong and Röel, 'Financing and Control'). For many companies, however, this appointments process was little more than a rubber-stamping exercise. It was the norm that key directeuren would also sit in on meetings of commissarissen.

${ }^{27}$ Jonker, 'Sinecures or Sinews'. 
${ }^{28}$ De Jong and Röell, 'Financing and Control', 497.

${ }^{29}$ De Vries et al., Worldwide Banking.

${ }^{30}$ Westerman, De Concentratie.

${ }^{31}$ De Wit and Van den Ende, 'The Emergence'.

${ }^{32}$ The Big Five aggregated to having 428 million guilders in share capital and reserves in 1923 (approximately 2,900 million euros in today's money), of which Robaver had 112 million and Ambank 100 million.

${ }^{33}$ The principal other casualties of the crisis were the middenstandsbanken, unit-independent banks for small- and medium-sized urban enterprises, many of which were under cooperative ownership (Colvin, 'Religion').

${ }^{34}$ Jonker, 'Sinecures or Sinews'; Jonker, 'Spoilt for Choice?'; Jonker and Van Zanden, 'Method in the Madness?'; and Jonker, “Between Private Responsibility'.

${ }^{35}$ Van Zanden, 'Old Rules'.

${ }^{36}$ Fisher, 'The Debt-Deflation Theory'.

${ }^{37}$ Petizimas, 'Icarus', argues that problems at the bank started as early as 1920, when shipping concerns Transmarina and Transoceana, both of which were eventually liquidated, required large bank loans to continue running over. He finds evidence that Robaver resorted to buying up shares in these firms in order to maintain the impression to outsiders that all was well with the businesses.

${ }^{38}$ De Vries et al., Worldwide Banking.

${ }^{39}$ Biographical sketch due to Ariëtte Dekker (Biography Institute, Rijksuniversiteit Groningen), who is preparing a biography of Anton Kröller as her $\mathrm{PhD}$ dissertation (scheduled for completion in 2015).

${ }^{40}$ Van Oss, Van Oss Effectengids.

${ }^{41}$ Jonker, 'Kröller'.

42 'Notulen van de Vergaderingen van de Directie', 2 November 1922, Inv. No. 145, Archief van het Hoofdkantoor van de Rotterdamsche Bank NV (henceforth ARB), Access No. 2.18.33, Nationaal Archief, The Hague.

${ }^{43}$ De Kroniek, 16 May 1923, pp. 28-29.

${ }^{44}$ All quoted material in this article is translated from the original Dutch by the author. 'Notulen van de Vergaderingen van de Directie', 11 September 1923, Inv. No. 146, ARB.

45 'Notulen van de Vergaderingen van de Directie', 4 October 1923, Inv. No. 146, ARB.

${ }^{46}$ This loan, and the others described in this article, disproves the assertion made in De Jong and Röel, 'Financing and Control', 492, that Dutch banks did not issue loans to firms with 
which they had managerial ties. However, it suggests that they sometimes took great lengths to hide such positions.

${ }^{47}$ Lichtenauer, 'Vorm'.

48 'Notulen van de Vergaderingen van het College van Commissarissen', 4 October 1923, Inv. No. 110, ARB.

${ }^{49}$ Van Oss.

${ }^{50}$ De Kroniek, 26 March, 378-379.

${ }^{51}$ Rotterdamsche Bankvereeniging, Annual Report 1924.

52 'Notulen van de Vergaderingen van het College van Commissarissen', 23 April 1924, Inv. No. 110, ARB.

${ }^{53}$ De Kroniek, 7 May 1924, 426-428.

${ }^{54}$ Ibid., 427.

${ }^{55}$ Ibid., 428.

56 'Notulen van de Vergaderingen van de Directie', 12 May 1924, Inv. No. 146, ARB.

57 'Notulen van de Vergaderingen can de Comité en Directie', 15 May 1924, Inv. No. 115, ARB. This new management structure appears to be similar to that proposed in October 1923 by commissaris Van der Vorm. Crucially, however, it did not require a change in the bank's statutes.

${ }^{58}$ Aside from Müller \& Co.'s business activities, the firm was apparently also used by Kröller and his wife to bankroll their personal art collection. Rovers, De Eeuwigheid, includes a detailed history of the collection's formation, which today is housed at the Kröller-Müller Museum in De Hoge Veluwe National Park.

59 'Notulen van de Vergaderingen van de Directie', 26 May 1924, Inv. No. 146, ARB.

60 'Notulen van de Vergaderingen can de Comité en Directie', 28 May 1924, Inv. No. 115, ARB.

61 'Notulen van de Vergaderingen van het College van Commissarissen', 5 June 1924, Inv. No. 110, ARB.

62 'Notulen van de Vergaderingen can de Comité en Directie', 12 June 1924, Inv. No. 115, ARB.

${ }^{63}$ De Kroniek, 16 June 1924, 472.

${ }^{64}$ De Kroniek, 1 July 1924, 488-489.

${ }^{65}$ De Vries, Geschiedenis, 249.

${ }^{66}$ Ibid., 252.

${ }^{67}$ De Kroniek, 1 July 1924, 488-489, wonders why DNB rather than Robaver itself did not publish the news. The article returns to the point it made in May that dividends should 
never have been paid out. It asks how DNB is able to finance its possible intervention and speculates that the government is involved, possibly surpassing its mandate. At this point, the government's role has yet to enter the public domain.

68 'Notulen van de Vergaderingen van het College van Commissarissen', 10 July 1924, Inv. No. 110, ARB.

69 'Notulen van de Vergaderingen van de Comité en Directie', 10 July 1924, Inv. No. 115, ARB. Ernst Heldring, a prominent Amsterdam businessman, wrote in his diary on 9 July that 'what I can observe leads me to believe that [...] people are withdrawing their accounts [from Robaver] and depositing them at other banks' (Heldring, Herinneringen, 568-570).

70 'Notulen van de Vergaderingen van de Comité en Directie', 10 July 1924, Inv. No. 115, ARB.

${ }^{71}$ Van Loon \& Co. was a brokering firm owned by Hope \& Co.'s Bank. It was only in 1927, with the passing of the government's budget, that parliament was made aware of the government's earlier support of Robaver (Tweede Kamer, 'Mededeeling'), with vocal opposition ensuing (Tweede Kamer, 'Memorie').

${ }^{72}$ De Kroniek, 15 July 1924, 507-508.

73 'Notulen van de Vergaderingen van het College van Commissarissen', 17 September 1924, Inv. No. 110, ARB.

${ }^{74}$ Petizimas, 'Icarus', argues that the 10 million guilders of Robaver shares came to Kröller in 1921 as a way of supporting the bank's share price through what he calls Robaver's "first crisis”, when difficulties with Transmarina, Transoceana and Kröller's Compañia Mercantil first came to light. These shares were apparently purchased with borrowed funds, and it is not at all impossible that these took the form of a bank loan from Robaver itself.

${ }^{75}$ De Vries, Geschiedenis.

76 'Notulen van de Vergaderingen van de Comité en Directie', 17 September 1924, Inv. No. 115, ARB.

${ }^{77}$ De Kroniek, 15 October 1924, 579-581.

${ }^{78}$ De Vries, Geschiedenis, argues that Vissering and Colijn jointly pushed Westerman sideways into his new job, and forced Robaver into accepting Van Hengel as caretaker president. The Robaver board had earlier expressed an interest in the Amsterdam private banker S.P. van Eeghen. Robaver's incumbent managers did not get their way.

${ }^{79}$ De Kroniek, 1 November 1924, 595-596.

${ }^{80}$ For example, 'Notulen van de Vergaderingen van de Directie', 17 December 1924, Inv. No. 147, ARB, recount how Van Hengel wants to replace Van Tienhoven on the supervisory board of Natobank. Van Tienhoven was allowed to retain his position following objection 
from Robaver's managers, although he does eventually stand aside. Van Hengel also pushed for the sale to the Twentsche Bank of the bank's flagship branch in The Hague, which housed the bank's management centre - an action that was abandoned.

81 'Stukken betreffende de sanering van Wm.H. Müller \& Co., 1924-1928', Inv. No. 3518, Archief van het Hoofdbank van de Amsterdamsche Bank NV (henceforth AAB), Access No. 2.18.32, Nationaal Archief, The Hague.

${ }^{82}$ The London Gazette, 22 November 1935, 7449

83 'Stukken betreffende de sanering van Wm.H. Müller \& Co., 1924-1928', Inv. No. 3518, $\mathrm{AAB}$.

${ }^{84}$ Jonker, 'Kröller'.

${ }^{85}$ Het Vaderland, 12 November 1936, D.3

${ }^{86}$ Scott, 'Theoretical Framework'.

${ }^{87}$ Ibid.

${ }^{88}$ Boot, 'Relationship Banking'.

${ }^{89}$ Benston, 'Universal Banking'.

${ }^{90}$ Boot and Thakor, 'Banking Scope'.

${ }^{91}$ Akerlof, 'The Market for Lemons'.

${ }^{92}$ Mishkin, 'Asymmetric Information'.

${ }^{93}$ Diamond and Dybvig, 'Bank Runs'. 
Figure 1. Equity-deposit ratio of the Amsterdamsche Bank (Ambank), the Rotterdamsche Bankvereeniging (Robaver) and the average of the Big Five Dutch commercial banks (Big5) for the period 1917 to 1931.

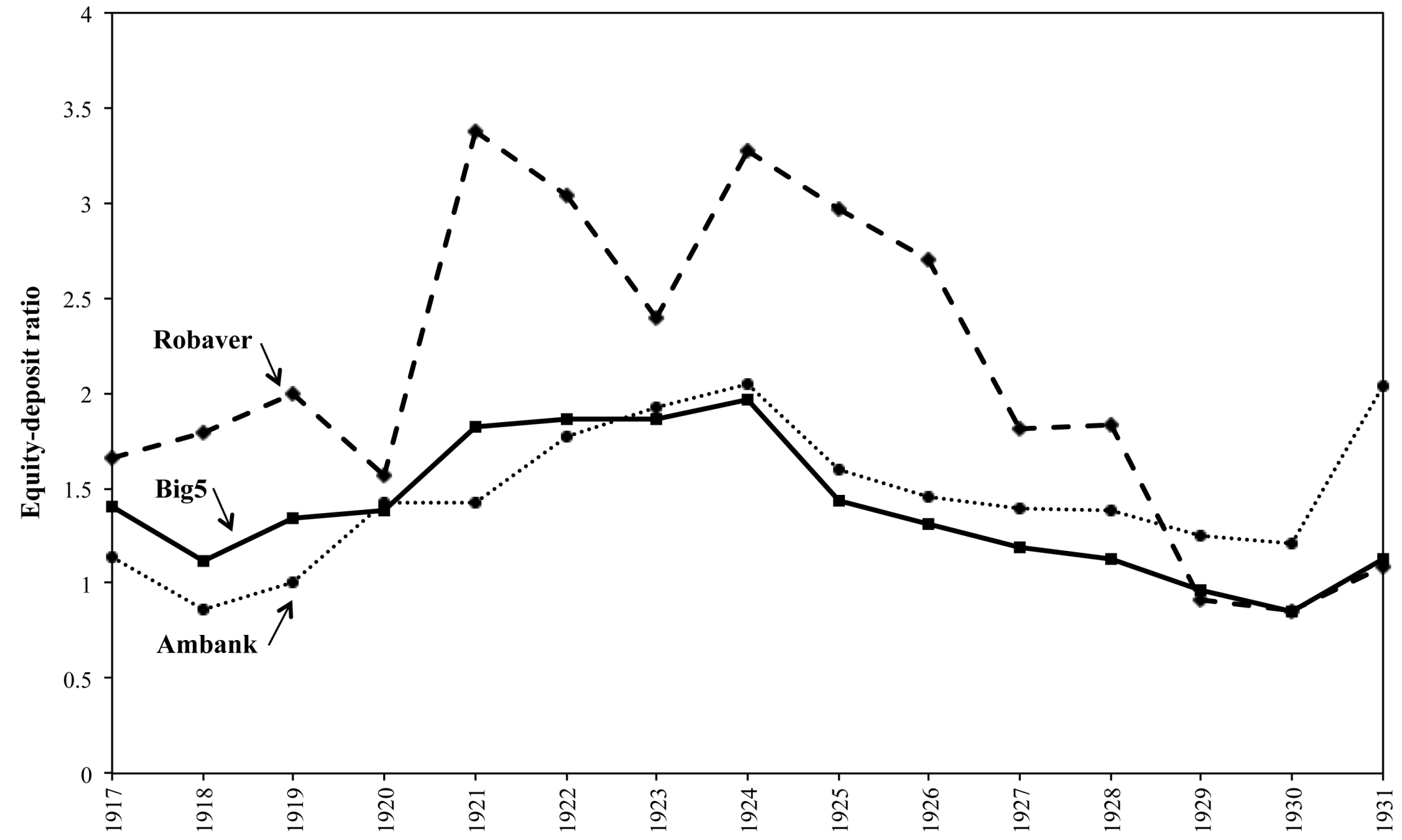

Notes: The equity-deposit ratio is calculated as banks' least liquid resources (capital plus reserves) divided by their most liquid ones (deposits plus savings). The Big5 Dutch commercial banks are Ambank, Incasso-Bank, Nederlandsche Handel Maatschappij, Robaver and Twentsche Bank. Source: Stichting voor Economisch Onderzoek der Universiteit van Amsterdam, 'Eerste Rapport'. 
Figure 2. The daily share price of the Amsterdamsche Bank (Ambank) and the Rotterdamsche Bankvereeniging (Robaver) in 1924.

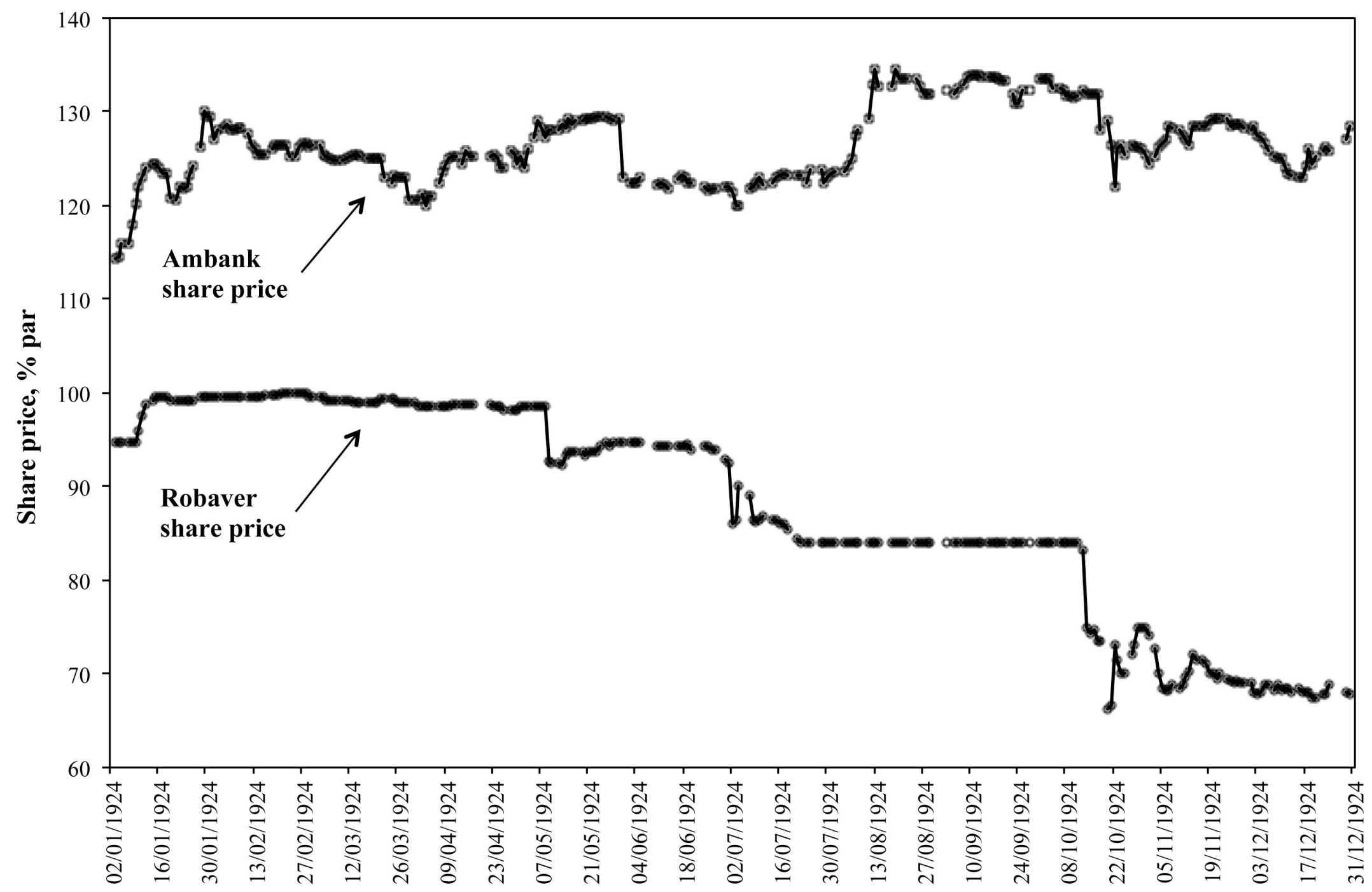

Notes: Share prices of companies listed on the Amsterdam stock exchange in the early twentieth century are quoted as a percentage of par value. Ambank had floated 55 million guilders worth of shares by the beginning of 1924, whilst Robaver had 75 million.

Source: Officiële Prijscourant, daily editions (Monday to Saturday) for the entirety of 1924. 